\title{
幼児の手指動作に関する研究
}

九州芸術工科大学人間工学
○杉本洋介

小林宏光 i.はじめに

近年、ナイフで鉊茟を削れない子供や、は しや鉊筆を正しく持てない子供が增えて問題 になっている。手指䖝は、生後数年間でめ さましく発連することか知られているが、最 近の跳幼少の生活罢境をみると過度の保讙に より道具に接する機会は少なく、堯具なども 受身なものが多く必すしも手指動作や知的能 力の発䢖によい罢境とはいえない。

本研究では、幼呪について稹木の槙み上げ、 鉊茟、はしの持ち方、身長を調べ相白の関係 について比較検討してみた。

II. 方 法

\section{1 ）被模少}

被㛟呪は北九州市内に在住する幼椎園巟の 年長（5.6〜6.5成）で、男先 27 人、女先 44 人、 計 71 人であった。

2 ) 樌木の櫴み上げ㛟査 凶1に示す稹木を使用 し 1 個すつなるべく高く 視み上げる检査を行った。

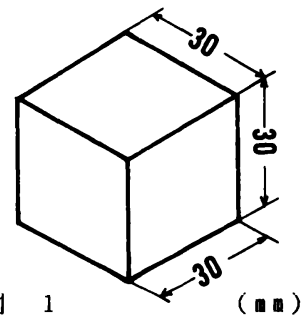

3) 鉊筆の持ち方㛟査

鉊簕の持ち方を忷 2 に示す様式に従って分 類した。

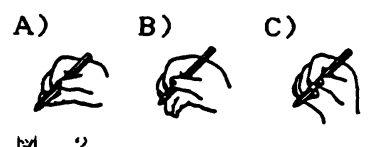

凶إ 2

A 型: 手は回内状㥿で、指と示指の間に物
を镇き手のひらは一部分を使朋する。 5 本の指をすべて使用する。

B 型：A型心位㽡に物を䯠くが、小指は使用 しない。

C型：A型の位瞋に物を置くが、小指、噮指 は使用しない。

変形した持ち方については、擆りに何本の 指が関与しているかでへてしの型に行類した。 $4)$ はしの持方方橹查

はしの持ち方を淛3に示す様式に说つて外 類した。
A)
B)
C)
D)

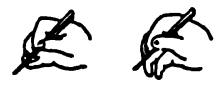
凶 3
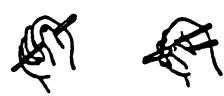

$\mathrm{A} \sim \mathrm{C}$ 型：基本的に鉊筆の持ち型と间じ分類 の仕方である。

D型： 4 本の指を使用した完成型。 1 本のは しを親指と罢指で固定し、もう 1 本の はしをしの型に握る。

変形した持ち方については、暒りに何本の 指が関与しているかでA〜しの型に分類した。 5 ) はしの使い方娭查

市敗のッィストマカロニを容器に用意し、 はしを使い、任意のマカロニを 1 個つまんで 别の容器に移す娭査を行った。2 回以内の試 行でできれば“うまくできる”、3 3 回以上 5 回以内の武行でできれば“どうにかできる”、 それ以上の試行を要するようであれば“うま くできない”と詊柤した。 


\section{世11. 結果}

鉊茟の持ち方を図4、はしの持ち方を図5 に示す。

月 27 人

A 1 , 1 ... 3.7x B aㅣ $6 \cdots 22.2 x$
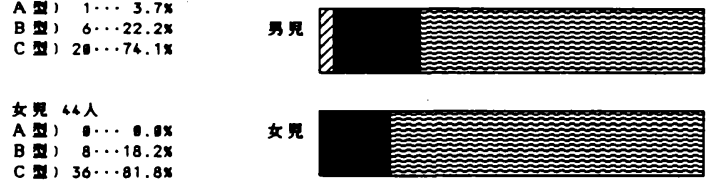

图 4
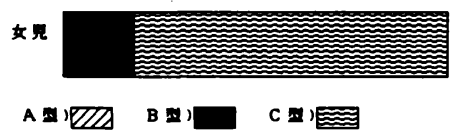

5 27 人

A 표 $3 \cdots 11.1 x$

B 질 $11 \cdots 40.7 x$

C 제) $12 \ldots 44.4 \times$

女胃 44人

A 제 $1 \cdots 2.3 \times$

B 표 $22 \cdots 50.0 x$

C 피 $19 \cdots 43.2 x$

図 5

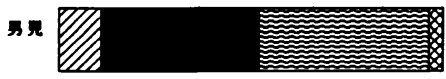

女吼

A $=12$ B

鉛筆、はしの持ち方ともに女览の方がい 傾问がある。鉊筆の持ち方とはしの持ち方を 比較したところ、型が一致した者は55\%であ り、鉊筆の持ち方に比へはしの持ち方がわる い者は38\%、よい者は7\%であった。

はしの持ち方を型别で分け、使い方の割合 を百分事で表したものを困6に示す。

\section{はしのッちカと需いカ}

$A=4$ 시

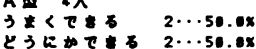

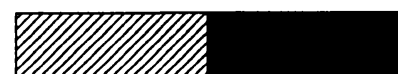

B $\mathbf{3} 33$ 人

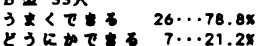

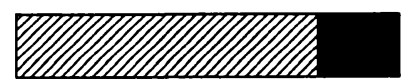

C 표 31 人

3 और

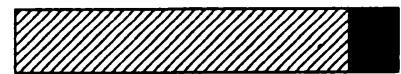

D国 3 人

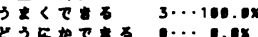

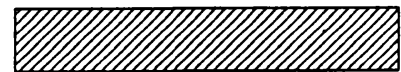

凶 6

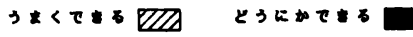

はしの持ち方がA型から口型になるに従つ て使い方の成結かよくっている。また、こ れは女㒭の方が成瞔がよかった。

鉛華の持ち方を A、B型とC型に分け、身 長と関連つけけて百分本で表したものを龱7に 示す。鉛筆の持ち方が A、B型の者とし型の 者を比べとと型の者の方が身長が高い傾向

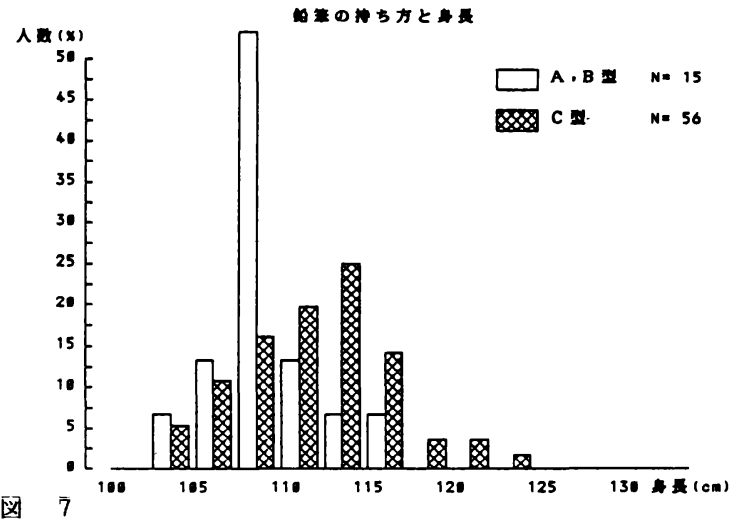

がある。

はしの持ち方を $\mathrm{A} 、 \overline{\mathrm{B}}$ 型とC、 $\mathrm{D}$ 型に分け、 積木の積み上げの個数㓢に人数の分布を百分 率で装したものを図8に示す。

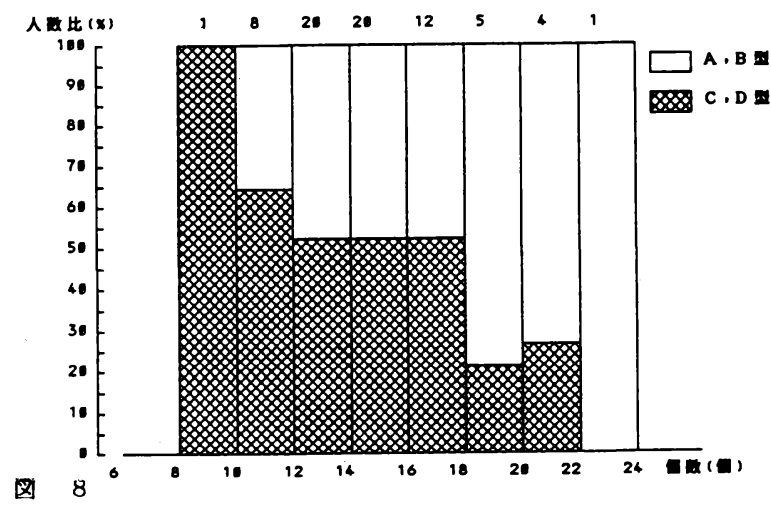

樍木を高く旗める者ほどはしの持ち方がわ るい攧向がある。これは鉊筆でも问㴍な期向 がみられた。

IV. 考察

铅華の持ち方よりはしの持ち方がわるくな っているのは、はしは2本の棒を漓調して的 かさな行ればならす襩雑であるからである。

はしの持ち方も稙木の䅡み上げもどちらも 高度な手指動作の発達を必要とするが、凶8 で反対の関係が垷れているのは、はしがマナ 一として教育される事柿であるのに対し、䅡 木の槙み上げは遊びを通しての経殹であり、 生活のなかでの幽者の片崙りが影零したもの と推湖される。 